\title{
Diagnostic comparison of Corynebacterium pseudotuberculosis through microbiological culture and PCR in sheep samples
}

\section{Comparação diagnóstica de Corynebacterium pseud otuberculosis pelo cultivo microbiológico e PCR em amostras ovinas}

\author{
Alessandra Figueiredo de Castro Nassar ${ }^{1 *}$, Gabriela Terezinha Daniel ${ }^{2}$, Regina Ruiz ${ }^{2}$, \\ Simone Miyashiro', Eloísa Maria Scannapieco', Juraci de Souza Neto ${ }^{3}$, Lilian Gregory ${ }^{4}$
}

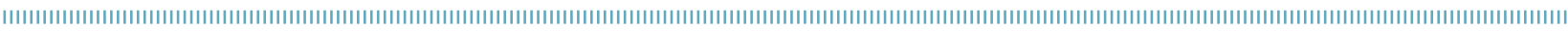

\begin{abstract}
Caseous lymphadenitis is a chronic infectious disease caused by Corynebacterium pseudotuberculosis, which is a bacterium responsible for a great number of economic losses on goat and sheep production. It is characterized by the formation of abscesses in superficial lymph nodes and in internal organs and lymph nodes. This study aimed at determining the agreement between microbiological culture and PCR in the identification of C. pseudotuberculosis, in samples collected from animals in slaughterhouses and in animals that presented lymph node enlargement in field conditions. From the 202 samples analyzed through microbiological culture, $113(56 \%)$ were positive for Corynebacterium sp.; from these positive samples, 38 (34\%) were identified as $C$. pseudotuberculosis by microbiological culture. From the amount of samples, $110(54 \%)$ were positive and 92 (46\%) were negative in the PCR. Kappa index (0.193) presented a weak agreement between PCR and microbiological culture. We concluded that molecular diagnosis (PCR) in clinical samples proved to be more efficient, reproducible, and faster than the microbiological culture, both on clinical samples analyses and in the confirmation of $C$. pseudotuberculosis in colonies that were classified by Corynebacterium genus. Thus, the present study demonstrated the importance of PCR to confirm $C$. pseudotuberculosis diagnosis, and the best contribution for the epidemiological surveillance of the disease in sheep.
\end{abstract}

KEYWORDS: C. pseudotuberculosis; sheep; microbiological culture; PCR.

\begin{abstract}
RESUMO: A linfadenite caseosa é uma doença infectocontagiosa crônica, causada pelo agente etiológico Corynebacterium pseudotuberculosis, que é uma bactéria responsável por grandes perdas econômicas na produção de ovinos e caprinos. Caracteriza-se pela formação de abscessos em nódulos linfáticos superficiais e em órgãos internos e linfonodos. O presente trabalho teve por objetivo verificar a concordância entre as metodologias de isolamento microbiológico com a PCR na identificação do C. pseudotuberculosis, em amostras clínicas colhidas em abatedouros e em animais que apresentavam aumento de linfonodo em condiçóes de campo. Das 202 amostras analisadas no cultivo microbiológico, 113 (56\%) foram positivas para o gênero Corynebacterium sp., e 38 (34\%) colônias foram identificadas como C. pseudotuberculosis por meio de cultura microbiológica. Das amostras clínicas extraídas, 110 (54\%) foram positivas e 92 (46\%) foram negativas na PCR. A concordância estimada entre as técnicas de PCR e o cultivo microbiológico pelo indicador Kappa foi considerada fraca $(0,193)$. Concluímos que o diagnóstico molecular (PCR) provou ser mais eficiente, rápido e com reprodutibilidade quando comparado ao cultivo microbiológico das amostras clínicas bem como da confirmaçáo do C. pseudotuberculosis de colônias pertencentes ao gênero Corynebacterium. Dessa forma, o presente trabalho demonstrou a importância do uso da PCR na confirmação diagnóstica do C. pseudotuberculosis, visando contribuir com a melhoria da vigilância epidemiológica da doença em ovinos.
\end{abstract}

PALAVRAS-CHAVE: C. pseudotuberculosis; ovinos; cultivo microbiológico; PCR.

\footnotetext{
'Instituto Biológico, Centro de Pesquisa e Desenvolvimento de Sanidade Animal - São Paulo (SP), Brazil.

2Instituto Biológico - São Paulo (SP), Brazil.

${ }^{3}$ Serviço de Inspeção Estadual - São Paulo (SP), Brazil.

${ }^{4}$ Faculdade de Medicina Veterinária e Zootecnia da Universidade de São Paulo (USP) - São Paulo (SP), Brazil.

*Corresponding author: nassar@biologico.sp.gov.br

Received on: 27/02/2013. Accepted on: 20/03/2015.
} 


\section{INTRODUCTION}

Caseous lymphadenitis is an infectious, transmissible and chronic disease of small ruminants that is caused by Corynebacterium pseudotuberculosis (BATEY, 1986; BenHAM, et al. 2002). The genus Corynebacterium is formed by small or pleomorphic coccobacilli that are microaerophilic $(5 \%$ $\mathrm{CO}_{2}$ ), tolerant to aerophilic conditions, nonspore-forming, and Gram positive (Collet et al., 1994). The disease is characterized by abscesses that may be internal or superficial, or may affect internal organs (Dorella et al., 2006). Parotideal, mandibular, superficial cervical, subiliac, popliteal, or mammary lymph nodes may be affected. However, in some cases, the disease may be asymptomatic, with internal abscesses in lungs and bronchial lymph nodes, which may cause chronic pneumonia, mesenteric lymphadenitis, and pyelonephritis (Paton et al., 1995).

Diagnosis is based on characteristics of the lesions (presence of external abscesses), and these confirmation relies on isolation and biochemical identification, mainly to differentiate opportunistic pathogens that also cause abscesses, such as Arcanobacterium pyogenes and Pasteurella multocida (Dercksen et al., 2000; Dorella et al., 2006). Most of the time, biochemical confirmation is not conclusive due to the large phenotypic variability of $C$. pseudotuberculosis (DerCKsen et al., 2000). Thus, PCR diagnosis using specific primers is easier to identify colonies, enabling the right classification of the microorganisms in their genus and species, which is an important aid in the control of outbreaks in any regions (ÇetinkaYA et al., 2002).

Such disease occurs worldwide, and severe issues due to it have been described in commercial flocks of many different countries (Paton et al., 1995; SAïD et al., 2002; ArSEnAult et al., 2003; Baird; Fontaine, 2007). In Brazil, Moura Costa et al. (1973) first reported caseous lymphadenitis in the state of Bahia. In a study carried out by Costa et al. (2002), the greatest prevalence of such disease in herds of sheep and goat was observed in Northeastern of Brazil. In the slaughterhouses of the South region of the country, the prevalence was of $8 \%$. In Rio de Janeiro, from 13 herds studied, 10 of them were infected; and from them, $12 \%$ of the animals presented clinical signs, and $22.5 \%$ were infected by $C$. pseudotuberculosis (Riet-Correa et al., 2001). Daniel et al. (2009) found positive results in $60 \%$ of the samples collected in slaughterhouses and farms where there were suspected cases of caseous lymphadenitis in the state of São Paulo, Brazil.

The aim of the present study was to analyze the agreement between microbiological culture and PCR in the identification of $C$. pseudotuberculosis in samples collected in slaughterhouses and in animals that presented lymph node enlargement at field conditions.

\section{MATERIAL AND METHODS}

\section{Samples}

Samples from lesions that suggested caseous lymphadenitis were collected from lungs, livers, hearts and mediastinal lymph nodes $(n=125)$ of sheep in a slaughterhouse. In addition, pus samples were aseptically taken from abscessed lymph nodes of naturally infected sheep herds $(\mathrm{n}=77)$ in Sorocaba, state of Sáo Paulo, Brazil. The 202 samples (under refrigeration and inside isothermal containers) were immediately sent to the General Bacteriology Laboratory of Instituto Biológico.

This paper has been realized according to the principles approved by Ethics Committee in use of animals at University of Sao Paulo, it has been approved at meeting on 06/22/2011, on the protocol number 2208/2011.

\section{Microbiological culture}

Material aspirated from lymph nodes and organs collected in the slaughterhouse was suspended by $1: 5(\mathrm{w} / \mathrm{v})$ in sterile saline solution $(0.85 \%)$, and $10 \mathrm{~mL}$ of the suspension were seeded on 5\% sheep blood agar and incubated for 48 hours at $37^{\circ} \mathrm{C}$. After the incubation period ended, when bacterial multiplication occurred in the medium, bacterioscopy by Gram stain was performed, and the bacterial species were identified by catalase, MacConkey agar, fermentation of glucose and lactose (TSI - triple sugar iron), motility, urease, nitrite reduction and gelatin liquefaction, according to QuinN et al. (2005) and Koneman et al. (2008).

\section{DNA isolation}

Two different protocols were adapted for extracting DNA from bacterial cultures and clinical samples.

\section{Bacterial cultures}

Isolated colonies that belonged to genus Corynebacterium sp. and C. pseudotuberculosis were resuspended in $100 \mu \mathrm{L}$ of $0.85 \%$ sterile saline solution and boiled for 10 minutes at $100^{\circ} \mathrm{C}$ (Bermer-Merchior; Drugeon, 1999).

\section{Clinical samples}

DNA extraction from clinical samples was conducted using DNAzol (Invitrogen ${ }^{\circ}$ ) from lymph node supernatant and (lungs, livers, hearts, and mediastinal lymph nodes) organ suspension diluted by $1: 5(\mathrm{w} / \mathrm{v})$ in $0.85 \%$. saline sterile solution. 


\section{MPCR}

For C. pseudotuberculis identification it was carried out the PCR technique described by PACHECo et al. (2007) adapted, because only primer was used this reaction. The pld gene with amplifies $203 \mathrm{pb}$ the gene C. pseudotuberculosis. This sequence of pld gene is present in both C. pseudotuberculosis and C. ulcerans, the PLD-F to amplify the pld genes of both bacteria and reverse primer (PLD-R1) detection C. pseudotuberculosis and primer PLD-R2 excluded C. ulcerans (table 1). The template concentration was approximately $10 \mathrm{ng}$ of DNA added of $40 \mathrm{~L}$ of the PCR mix containing 1.25 U Taq DNA polymerase (Invitrogen ${ }^{\circ}$ ), $200 \mathrm{M}$ of each deoxynucleotide, buffer $(10 \mathrm{mM}$ Tris- $\mathrm{HCl}, \mathrm{pH} 8.0 ; 50 \mathrm{mM}$ $\mathrm{KCl}$ ); $2 \mathrm{mM} \mathrm{MgCl}_{2}$, and $0.5 \mathrm{M}$ of each primer. As positive control, used C. pseudotuberculosis from the Instituto Biológico and C. ulcerans (CDC KC279), and ultrapure water was used as negative control. The amplification protocol was: denaturation at $95^{\circ} \mathrm{C}$ for $3 \mathrm{~min} ; 30$ cycles of $95^{\circ} \mathrm{C}$ for $1 \mathrm{~min} ; 58^{\circ} \mathrm{C}$ for $40 \mathrm{~s}$ and $72^{\circ} \mathrm{C}$ for $1 \mathrm{~min}$, final extension at $72^{\circ} \mathrm{C}$ for $7 \mathrm{~min}$. the amplified products were resolved by electrophoresis on $1.0 \%(\mathrm{w} / \mathrm{v})$ agarose gels and visualized by Sybr Safe (Invitrogen $\left.{ }^{\circ}\right) 0.5 \mathrm{~g} / \mathrm{mL}$.

\section{Statistical analysis}

The Kappa index, expressing the correlation between the PCR and microbiological results, was obtained using the Minitab program, version 16.

\section{RESULTS}

Two-hundred and two clinical samples (Fig. 1), from animals with lesions suggestive of caseous lymphadenitis, were analyzed.

From such amount, 113 cultures $(56 \%)$ were positive for the Corynebacterium sp. genus, 38 of them (34\%) were identified as $C$. pseudotuberculosis by the following biochemical tests: catalase production, variable fermentation of glucose and lactose, negative motility, positive urease, negative nitrite reduction, and negative gelatin liquefaction. Other bacterial agents were isolated and biochemical methods were conducted in the 202 analyzed samples: Staphylococcus sp. (45.5\%), Bacillus sp. (38\%), Corynebacterium sp. (7\%), Enterobacteria (6.5\%), Pseudomonas sp. (3\%), Escherichia coli (3\%), Acinetobacter sp. (2.5\%), Serratia marcescens (2\%), Streptococcus sp. (2\%),
Citrobacter freundii (2\%), Klebsiella ozaeneae (1.5\%), Actinomyces sp. (1\%), Klebsiella pneumoniae (0.5\%), Enterobacter gergoviae $(0.5 \%)$, and non-fermenting Gram-negative bacilli (8\%).

From 113 colonies isolated through microbiological culture and identified as Corynebacterium sp., 90 (80\%) were positive in the PCR for $C$. pseudotuberculosis. (Fig. 2). PCR results for DNA extracted directly from clinical samples presented 110 (54\%) positive samples, and $92(46 \%)$ negative ones for $C$. pseudotuberculosis. From the 110 positive ones in the PCR, 64 (58\%) were confirmed through C. pseudotuberculosis, 10 (9.3\%) were identified as belonging to Corynebacterium sp. genus (negative in the PCR for C. pseudotuberculosis), and $34(31 \%)$ did not present growth in microbiological culture.

According to the literature, the agent shows the following biochemical profile (Konemam et al., 2008): variable utilization of glucose and lactose; variable gelatin liquefaction; positive urease activity; negative nitrate reduction, and motility. The present study has found 12 profiles, and three of them were confirmed as C. pseudotuberculosis in the microbiological culture. PCR presented other nine different identification profiles.

From data presented on Table 2, we concluded that all isolates that were Gram positive, non-motile coccobacilli, non-producers of gelatinase, showed variable nitrate to nitrite reduction and urease production, and the following possible TSI profiles:

- positive glucose and variable lactose, or

- negative glucose and negative lactose, were confirmed as C. pseudotuberculosis by molecular methods.

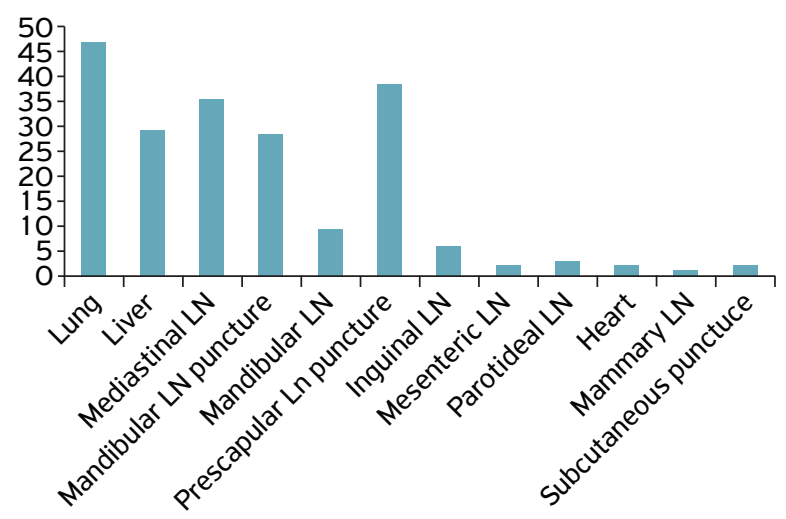

LN: Iymph nodes

Figure 1. Distribution of sheep tissue samples analyzed in this study. Samples were collected from animals in a slaughterhouse and from naturally infected sheep.

Table 1. Sequence of oligonucleotide primers for C. pseudotuberculosis detection adapted of PACHECO et al. (2007).

\begin{tabular}{cccc}
\hline & Primers & Sequence (5'-3') & Length of PCR products \\
\cline { 2 - 3 } pld & PLD-F & ATAAGGTAAGCAGGGAGGA & $203 \mathrm{pb}$ \\
\cline { 2 - 4 } & PLD-R1 & ATCAGCGGTGATTGTCTTCC & 20 \\
\hline
\end{tabular}




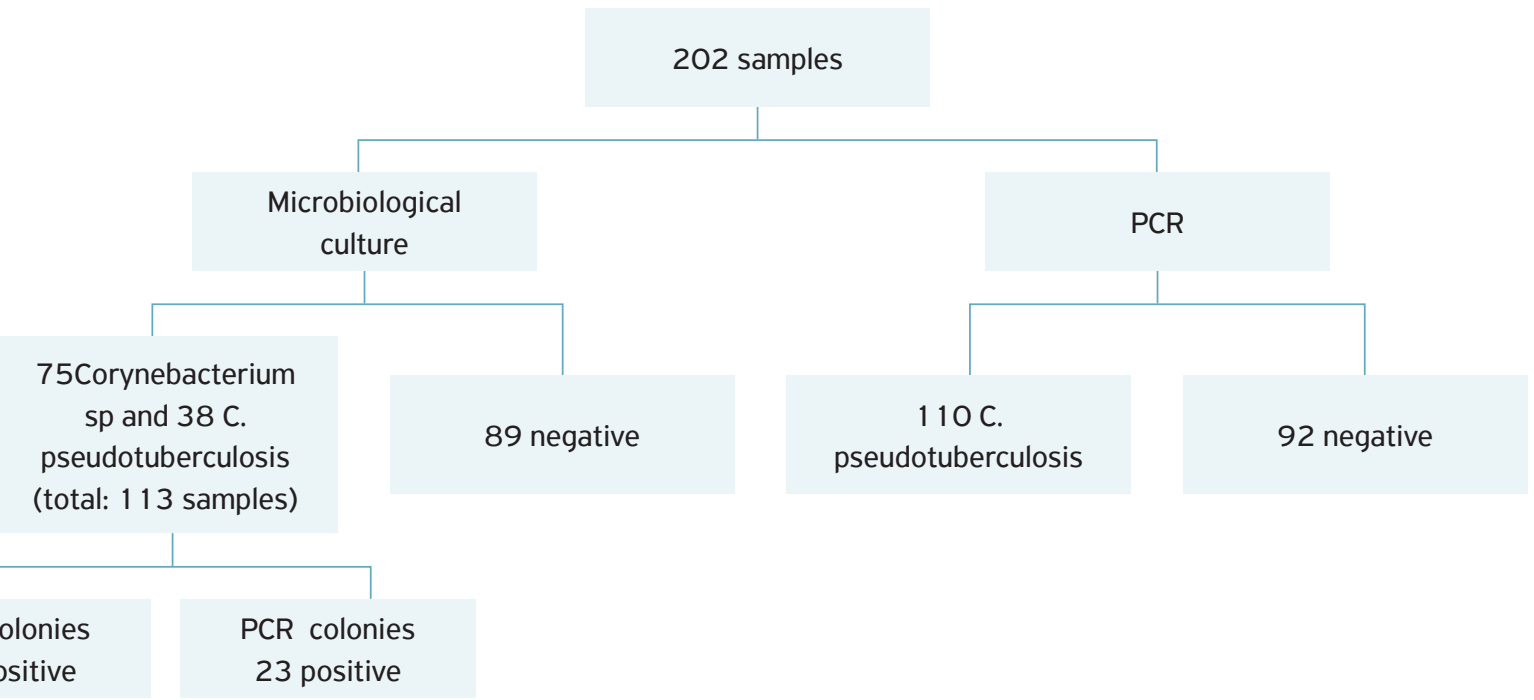

Figure 2. Distribution of results obtained in microbiology assays and multiplex-PCR made using sheep tissue samples.

Table 2. Correlation between biochemical profiles and PCR in colonies isolated from clinical samples of sheep suspected of caseous lymphadenitis, Sao Paulo, 2013.

\begin{tabular}{|c|c|c|c|c|c|c|c|}
\hline $\begin{array}{l}\text { Groups / } \\
\text { Animals }\end{array}$ & TSI & Motility & $\begin{array}{l}\text { Nitrate } \\
\text { reduction }\end{array}$ & Urea & Gelatin & Culture results & PCR results \\
\hline 16 & $G(-) L(-)$ & - & - & - & - & Corynebacterium sp. & C. pseudotuberculosis \\
\hline 18 & $G(+) L(+)$ & - & - & - & - & Corynebacterium sp. & C. pseudotuberculosis \\
\hline 2 & $G(+) L(-)$ & - & + & - & - & Corynebacterium sp. & C. pseudotuberculosis \\
\hline 2 & $G(-) L(-)$ & - & + & - & - & Corynebacterium sp. & C. pseudotuberculosis \\
\hline 2 & $G(+) L(+)$ & - & + & + & - & Corynebacterium sp. & C. pseudotuberculosis \\
\hline 4 & $G(+) L(-)$ & - & - & - & - & Corynebacterium sp. & C. pseudotuberculosis \\
\hline 7 & $G(+) L(+)$ & - & - & + & - & C. pseudotuberculosis & C. pseudotuberculosis \\
\hline 26 & $G(+) L(-)$ & - & - & + & - & C. pseudotuberculosis & C. pseudotuberculosis \\
\hline 3 & $G(-) L(-)$ & - & + & + & - & Corynebacterium sp. & C. pseudotuberculosis \\
\hline 5 & $G(-) L(-)$ & - & - & + & - & C. pseudotuberculosis & C. pseudotuberculosis \\
\hline 3 & $G(+) L(-)$ & - & + & + & - & Corynebacterium sp. & C. pseudotuberculosis \\
\hline 1 & $G(+) L(+)$ & - & + & + & - & Corynebacterium sp. & C. pseudotuberculosis \\
\hline
\end{tabular}

TSI: triple sugar iron; G: glucose; L: lactose

In the classification of the samples analyzed by PCR and microbiological culture, Kappa index presented a weak agreement $(k=0.193)$ between microbiological culture and PCR.

\section{DISCUSSION}

The present study analyzed 202 samples collected from sheep with lesions suggestive of caseous lymphadenitis in a slaughterhouse located in the state of São Paulo and from naturally infected animals. From a total of samples, 113 (56\%) were positive for Corynebacterium sp. genus, and only 38 (34\%) were identified as $C$. pseudotuberculosis in biochemical tests. PCR presented 110 (54\%) positive samples for C. pseudotuberculosis.
KHAMis et al. (2005) have reported the importance of using molecular methods (PCR, RFLP) to confirm the genus and species in coryneform bacteria, once biochemical tests used in the identification of $C$. pseudotuberculosis produce variable results. ÇetinkayA et al. (2002) consider biochemical identification as not reliable and PCR as useful. Thus, the latter method is quick and specific to identify the colonies. It is also sensitive to detect the agent directly from clinical samples.

In the present study, we compared the results from microbiological assays and PCR of colonies, and 12 possible biochemical profiles were found for $C$. pseudotuberculosis. This finding corroborates the results of KHAMIs et al. (2005), ÇETINKAYA et al. (2002), and PACHECo et al. (2007), who have reported a wide variation in the biochemical characteristics of Corynebacterium species, a situation that represents an issue in differentiation of 
species in this genus. On the other hand, PACHECO et al. (2007) have stated that one of the disadvantages of PCR was that it depended on microbiological culture. However, the present study showed that PCR of clinical samples detected a larger number of positive samples than microbiological culture. This finding is supported by the weak agreement $(0.193)$ between microbiological culture and PCR calculated using the Kappa index, given by the higher analytical sensitivity of PCR compared with microbiological culture. SoNGER et al. (1988) and SutherLand et al. (1996) defined two genotypic profiles in the identification of $C$. pseudotuberculosis, based on differences in the ability of the bacterium to reduce nitrate: nitrite-positive isolates came from horses (C. pseudotuberculosis biovar equi), and nitrite-negative isolates from sheep and goats (C. pseudotuberculosis biovar ovis). However, in this investigation, six groups (16 animals) were positive for nitrate reduction and confirmed $C$. pseudotuberculosis through PCR. Miers; Ley (1980) found 117 cases of ulcerative lymphangitis caused by C. pseudotuberculosis in horses, and one sample was negative for nitrate reduction, differently from the genotypic profiles determined by SONGER et al. (1988) and SutherLand et al. (1996).

Besides biochemical variability, microbiological culture has the disadvantage of being related to the isolation of opportunistic microorganisms that grow faster and prevent $C$. pseudotuberculosis from being detected, since this bacterium requires a 48-hour incubation period in aerobiosis to form colonies (Connor et al., 2000). Cultures of organs and their contents show several bacterial agents, with greater incidence of the genera Bacillus sp. and Staphylococcus sp. On the other hand, AвREu et al. (2008) found several infectious agents associated with C. pseudotuberculosis, mainly Staphylococcus sp. and other unidentified Gram-negative bacteria. SAïD et al. (2002) also reported the presence of genera Staphylococcus aureus subps.
Anaerobius and Streptococcus sp., among others, but none of these studies indicated the presence of Arcanobacterium pyogenes and Pasteurella multocida, which may cause purulent lesions similar to C. pseudotuberculosis (DERCKSEn et al., 2000; Dorella et al., 2006).

In $33 \%$ of the samples from this study, where the genus Bacillus sp. was isolated (data not presented), the species C. pseudotuberculosis was detected only in the PCR of the clinical samples, suggesting that the use of PCR prevented this interference with the agent detection. In the present study, from the 202 samples collected, 35 were from mediastinal lymph nodes, and from these $28(80 \%)$ were positive for C. pseudotuberculosis. These data corroborate the findings of FonTAINE et al. (2006), who described that experimentally infected animals with C. psendotuberculosis by subcutaneous route developed primary foci infection in mediastinal lymph nodes, followed by the lungs. STOops et al. (1984) also reported that only $26 \%$ of the animals with caseous lymphadenitis had apparent symptoms. This is in agreement with ARSENAULT et al. (2003) findings, which indicated that $26 \%$ of the sheep with caseous lymphadenitis slaughtered in Canada presented apparent lesions. Herein, $32 \%$ of the slaughtered animals showed lesions only in internal organs, mainly in mediastinal lymph nodes and lungs, without any visible lesions and enlargement of external lymph nodes. This is the most important finding for the disease epidemiological control, since the transmission involves contact with nasal secretions and aerosols (ELLis et al., 1987; PATON et al., 1995). In addition, animals that do not present overt disease are important sources of infection.

We concluded that molecular diagnosis (PCR) in clinical samples has proved to be more efficient, reproducible and faster than microbiological culture, both in clinical samples and in the confirmation of C. pseudotuberculosis colonies classified by belonging to genus Corynebacterium.

\section{REFERENCES}

ABREU, S.R.O.; MOTA, R.A.; ROSINHA, G.M.S.; FORNER, O.; PINHEIRO JUNIOR, J.W.; PEREIRA, R.R.B.; CASTRO, R.S.; ELISEI, C.; SOARES, C.O.; ARAÚJO, F.R.; MADUREIRA, R.C. Comparação genotípica de isolados de Corynebacterium pseudotuberculosis de caprinos e ovinos do sertão de Pernambuco. Pesquisa Veterinária Brasileira, v.28, p.481-487, 2008.

ARSENAULT, J.; GIRARD, C.; DUBREUIL, P.; DAIGNAULT, D.; GALAMEAU, J.R.; BOISCLAIR, J.; SIMARD, C.; BÉLANGER, D. Prevalence of and carcass condemnation from maedi-visna, paratuberculosis and caseous lymphadenitis in culled sheep from Quebec, Canada. Prevent Veterinary Medicine, v.59, p.67-81, 2003.

BAIRD, G.J.; FONTAINE, M.C. Corynebacterium pseudotuberculosis and its role in ovine caseous lymphadenitis. Journal of Comparative Pathology, v.137, p.179-210, 2007.
BATEY, R.G. Pathogenesis of caseous Iymphadenitis in sheep and goats. Australian Veterinary Journal, n.63, p.269-272, 1986.

BENHAM, C.L.; SEAMAN, A.; WOODBINE, M. Corynebacterium pseudotuberculosis and its role in diseases of animals. Community Bureau of Animal Health, v.32, p.645-657, 2002.

BERMER-MERCHIOR, P.; DRUGEON, H.B. Inactivation of mycobacterium tuberculosis for DNA typing analysis. Journal of Clinical Microbiology, v.37, p.2350-2351, 1999.

ÇETINKAYA, B.; KARAHAN, M.; ATIL, E.; KALIN, R.; DE BAERE, T.; VENEECHOUTTE, M. Identification of Corynebacterium pseudotuberculosis isolates from sheep and goats by PCR. Veterinary of Microbiology, v.88, p.75-83, 2002. 
COLLETT, M.G.; BATH, G.F.; CAMERON, C.M. Corynebacterium pseudotuberculosis infections. In: Infections diseases of livestock with special reference to Southern Africa. v. 2. New York: Oxford University Press, 1994. p.1387-1395.

CONNOR, K.M.; QUIRIE, M.M.; BAIRD, G.; DONACHIE, W. Characterization of United Kingdom isolates of Corynebacterium pseudotuberculosis using pulsed-field gel eletroforesis. Journal of Clinical Microbiology, v.38, p.2633-2637, 2000.

COSTA, L.F.M. Corynebacterium pseudotuberculosis, o agente etiológico da linfadenite caseosa em caprinos. Brazilian Journal of Medical and Biological Research, v.1, n.1, p.105$115,2002$.

DANIEL, G.T.; MIYASHIRO, S.; NASSAR, A.F.C. Detecção de Corynebacterium pseudotuberculosis através do cultivo microbiológico e PCR em amostras ovinas suspeitas de linfadenite caseosa no Estado de São Paulo, SP. Biológico, São Paulo, v.7 1, n.2, p.23, 2009.

DERCKSEN, D.P.; BRINKHOF, J.M.A.; DEKKER-NOOREN, T.; VAN MAANEM, K.; BODE, C.F.; BAIRD, G.; KAMP, E.M. A comparison of four serological test for the diagnosis of caseous lymphadenitis in sheep and goats. Veterinary of Microbiology, v.75, p.167175,2000

DORELLA, F.A.; PACHECO, L.G.C.; MIYOSHI, A.; AZEVEDO, V. Corynebacterium pseudotuberculosis microbiology, biochemical properties, pathogenesis and molecular studies of virulence. Veterinary. Research, v.37, p.201-218, 2006.

ELLIS, J.A.; HAWK, D.A.; HOLLER, L.D.; MILLS, K.W.; PRATT, D.L. Differential antibody responses to Corynebacterium pseudotuberculosis in sheep with naturally acquired caseous lymphadenitis. Journal of the American Veterinary Medical Association, v.196, n.10, p.1609-1613, 1990.

FONTAINE, M.C.; BAIRD, G.; CONNOR, K.M.; RUDGE, K.; SALES, J.; DONACHIE, W. Vaccination confers significant protection of sheep against infection with the virulent United Kingdon strain of Corynebacterium pseudotuberculosis. Vaccine, v.24, p.59865996, 2006.

KHAMIS, A.; RAOULT, D.; SCOLA, B.L. rpoB Gene Sequencing for Identification of Corynebacterium Species. Journal of Clinical Microbiology, v.42, p.3925-3931, 2005.

KONEMAN, E.W.; WILLIAM, M.J.; SCHRECKENBERGER, P.C.; WINN, W.C.; ALLEN, S.D.; WOODS, G.L. Diagnóstico microbiológico: texto e atlas colorido. In: Bacilos Gram-positivos aeróbicos e facultativos. Rio de Janeiro: Guanabara Koogan, 2008. p.760-851.
MIERS, K.; LEY, W.B. Corynebacterium pseudotuberculosis in the horse: Study of 117 clinical cases and consideration of ethiopathogenesis. Journal of the American Veterinary Association, v. 177 , p. 250-253, 1980.

MOURA-COSTA, M.D.; CAMARA, J.Q.; ROCHA, J.V.N.; MARTINEZ, T.C.N. Linfadenite caseosa dos caprinos no Estado da Bahia. Distribuição geográfica da doença. Boletim do Instituto Biológico da Bahia, v.12, n.1, p.1-7, 1973.

PACHECO, L.G.C.; PENA, R.R.; CASTRO, T.L.P.; DORELLA, F.A.; BAHIA, R.C.; CARMINATI, R.; FROTA, M.N.L.; OLIVEIRA, S.C.; MEYER, R.; ALVES, F.S.F.; MIYOSHI, A.; AZEVEDO, V. Multiplex PCR assay for identification of Corynebacterium pseudotuberculosis from pure cultures and for rapid detection of this pathogen in clinical samples. Journal of Medical Microbiology, v.59, p.480486, 2007.

PATON, M.W.; SUTHERLAND, S.S.; ROSE, I.R.; HART, R.A.; ELLIS, T.M. The spread of Corynebacterium pseudotuberculosis infection to unvaccinated and vaccinated sheep. Australian Veterinary Journal, v.72, n.7, p.266-269, 1995.

QUINN, P.J.; MARKEY, B.K.; CARTER, M.E.; DONNELLY, W.J.; LEONARD, F.C. Capítulo 10 - Gênero Corynebacterium. In: Microbiologia Veterinária e Doenças Infecciosas. Porto Alegre: Artmed Editora, 2005. p.67-70.

RIET-CORREA, F.; SCHILD, A.L.; MENDEZ, M.D.C.; LEMOS, R.A.A. Doenças de ruminantes e eqüinos. 2. ed. São Paulo: Livraria Varela, 2001.425p.

SAIID, M.S.B.; MAITIGUE, H.B.; BENZARTI, M.; REJEB, A.; AMARA, A. Contribuition a l'etude epidemiologique et clinique de La lymphadenite caseuse chez lês ovins. Archives de Institut Pasteur de Tunis, v.79, p.51-57, 2002.

SONGER, J.G.; BECKENBACH, K.; MARSHALL, M.M.; OLSON, G.B.; KELLEY, L. Biochemical and genetic characterization of Corynebacterium pseudotuberculosis. American Journal of Veterinary Research, v.2, n.49, p. 223-226, 1988.

STOOPS, S.G.; RENSHAW, H.W; THILSTED, J.P. Ovine caseous lymphadenitis: disease prevalence, lesion distribution, and thoracic manifestations in a population of mature culled sheep from western United States. American Journal of Veterinary Research, v.45, p.557-561, 1984.

SUTHERLAND, S.S.; HART, R.A.; BULLER, N.B. Genetic differences between nitrate-negative and nitrate-positive $C$. pseudotuberculosis strains using restriction fragments length polymorphisms. Veterinary Microbiology, v.49, p.1-9, 1996. 